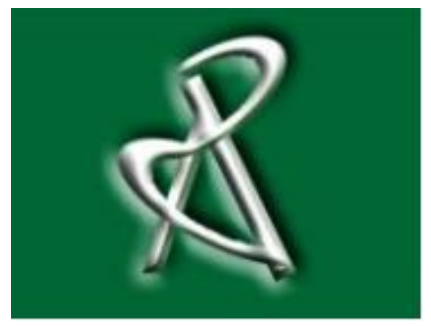

Available online at www.academicpaper.org

Academic @ Paper

ISSN 2146-9067

International Journal of Automotive Engineering and Technologies

International Journal of Automotive

Engineering and Technologies

http://www.academicpaper.org index.php/IJAET

Vol. 5, Issue 1, pp. 8-16, 2016

Original Research Article

\title{
Experimental investigation of coating in a diesel engine for improved exhaust emissions and performance
}

\author{
Hanbey Hazar ${ }^{1 *}$, Uğur Öztürk ${ }^{1}$ \\ ${ }^{1}$ Department of Automotive Engineering, Technology Faculty, Firat University, Elazig 23119, Turkey
}

Received 04 November 2015 Accepted 01 March 2016

\begin{abstract}
In this study, adiabatic property was brought to a 4-cylinder natural aspirated, direct injection diesel engine. For this purpose, cylinder liner, piston upper surface and valves were coated with powder with boron. Solid-boronizing method and plasma spray method were used as coating method. While cylinder liner and valves were coated with the layer of $\mathrm{Fe}_{2} \mathrm{~B}$ in the thickness of 150 micron by using solid boronizing method, piston upper surface was coated with the layer of CoNiCrAlYttra +NiCrBSi in the thickness of 300 micron by using plasma spray method. After the coating process, the engine was subject to performance and emission tests. ASTM-D-2 fuel was used as test fuel. As a result of tests, while BSFC value of coated engine decreased at the rate of $7.5 \%$ and BSEC value decreased at the rate of $7 \%$ and at the rate of $15 \%$ in EGT value. While a decrease was observed at the rate of $10 \%$ in CO value, 47\% in $\mathrm{HC}$ value, and 14\% in Smoke value, an increase was observed at the rate of 35\% in NOx value.

Keywords: Adiabatic engine, boronizing, plasma spray, coating, $\mathrm{Fe}_{2} \mathrm{~B}$, performance, emission
\end{abstract}

doi: 10.18245/ijaet.47076

*Corresponding Author:

Tel. : : +90 4242370000 Ext. 4363

E-mail : hanbeyhazar@hotmail.com 


\section{Introduction}

Numerous methods are used in industry in order to improve surface properties of materials. These methods are generally named as surface modification methods and can be applied on the material in terms of physical, chemical, thermal or thermochemical aspectsAs a result of these processes, unique characteristics of material could be changed and developedWhen the operating conditions of internal combustion engines are considered; undesired conditions for material appear on especially the surface of combustion chamber elements due to the nature of combustion such as high temperature, high pressure, irregular thermal stresses and shocks, friction, wear, acidic environment, and corrosive environment. These conditions damage surface quality of pieces by causing deformation and failures on the surface of material in progressive repeated processes and subsequently cause the working efficiency of engine to decreaseAccordingly, an unqualified combustion creates a harmful emission and harms the environment. At this point, surface modifications are seen as the most efficient solution in preventing or completely removing these negative effects. Thanks to thermal insulation to be applied to combustion chamber, it is possible to decrease heat losses and increase the efficiency of thermal cycle of engine by eliminating cooling system. For this, a modification is required on combustion chamber elements. Installing a heat conversion system that could transform heat losses into an efficient way could be costly. Even though no heat conversion system is used, a part of heat could be transformed to performance over pistons in order to increase thermal efficiency. When thermal barrier coating is applied on cylinder liner, piston peak, ring, and cylinder peak, heat loss passing over surfaces is prevented. Insulation of combustion chamber affects combustion event positively and improves engine performance and exhaust emissions [1,2]. Main principle of LHR engines is based on increasing thermal efficiency by decreasing heat losses going to cooler. Brake thermal efficiency of coated diesel engine is higher than normal engine. The increase in thermal efficiency is based on preventing the temperature used for cooling as well as lower heat flow. Additionally, it is reported that because of structural properties of LHR engine, BSFC values decrease and consequently the brake thermal efficiency increases [3-6]. Within the scope of this study, cylinder liner's internal wall and valves were coated with powder with boron by using pack boronising method for the first time. While piston upper surface was coated, plasma spray method was used. As a result of coating process, a coating layer with lower heat transmission was obtained on the surface of combustion chamber parts. Thus, thermal insulation was provided in combustion chamber, which enabled us to control the temperature distribution and heat flow in the engineWith thermal coating layer, heat transfer was decreased on internal surfaces of cylinder, in other words, cylinder walls, where temperature and fluid density change rapidly. Since this situation positively affects chemistry of combustion event and due to emerging adiabatic environment, the efficiency of combustion increased, and a positive contribution was provided to fuel economy by reducing fuel consumption values.

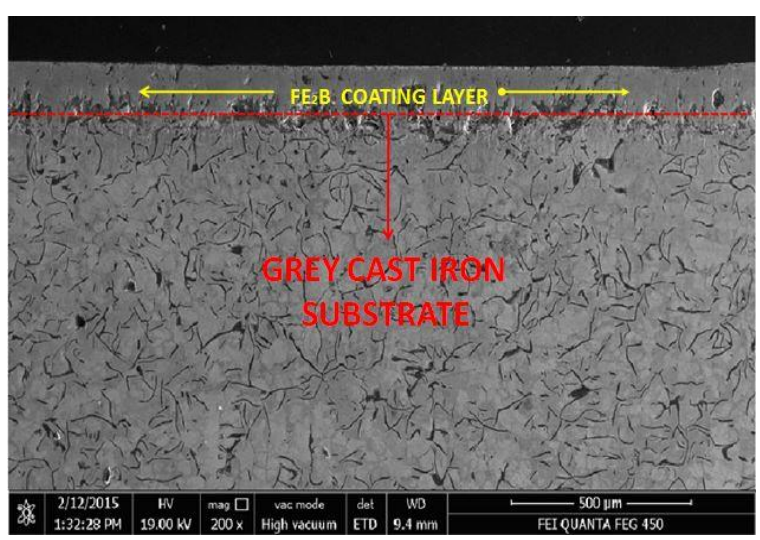

Figure 1. SEM cross-section image of cylinder liner and emerging $\mathrm{FE}_{2} \mathrm{~B}$ layer

\section{Engine Modification}

During this experimental study; cylinder liner, valve, and piston upper surface of a 4 cylinder direct injection diesel engine were 
coated with materials with boron. While cylinder liner and valves were coated, solid boronising method was used. Figure 1 illustrates SEM cross-section image of cylinder liner and emerging $\mathrm{FE}_{2} \mathrm{~B}$ layer.

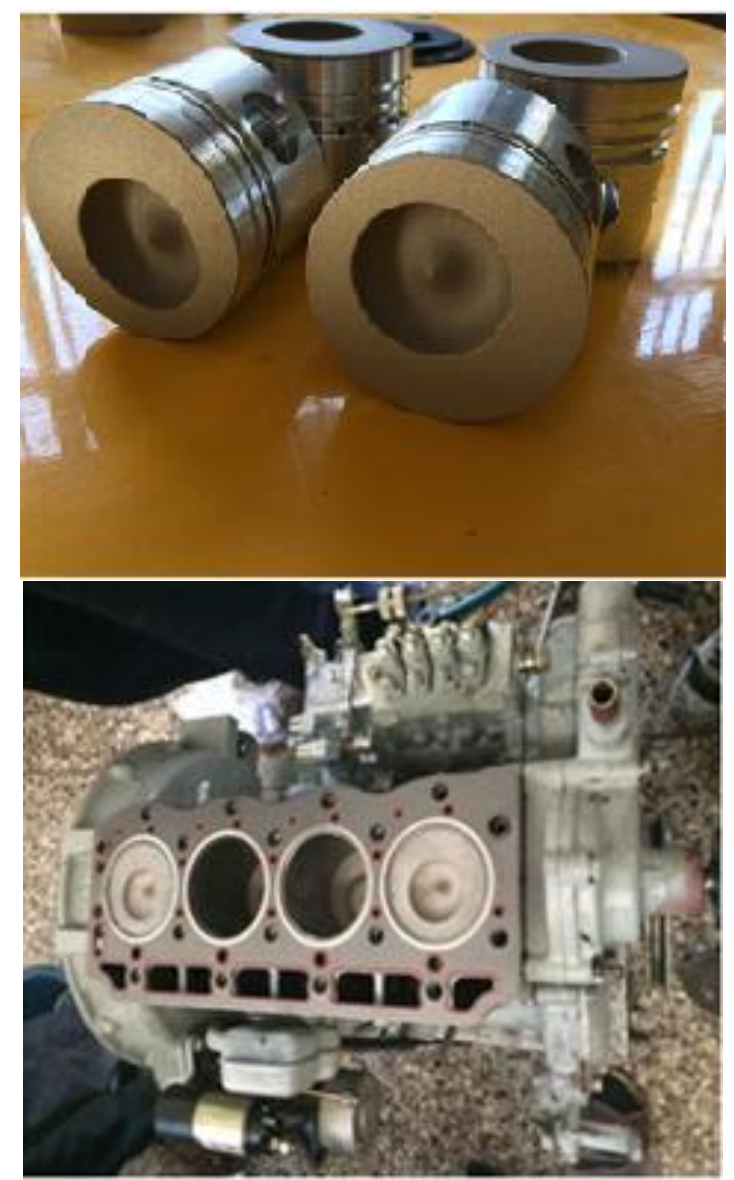

Figure 2. Image of integration of coated parts to engine.

Piston upper surface was coated by using atmospheric plasma spray method. Before coating piston upper surface, $300 \mu \mathrm{m}$ chips were removed from piston upper surface by considering that it will change compression ratio of engine. Coating process has started by spraying the bonder material (CoNiCrAlYttra) with the thickness of $50 \mu \mathrm{m}$ each to the surface in the first stage and then ended by spraying NiCrBSi powder in the thickness of $250 \mu \mathrm{m}$ on this bonder layer. Thus, a coating layer with boron in the thickness of $300 \mu \mathrm{m}$ was obtained on piston upper surface. As a result of these coating processes, a surface with high heat transmission resistance, low wear and friction coefficient on the surface of material was obtained, and the engine was brought a complete adiabatic characteristic. Thus, the engine was transformed into a thermal insulated engine (LHR). Table 1 illustrates heat transmission coefficient of coating layers. Figure 2 illustrates image of all coated parts. Finally, all coated parts were integrated to engine and the engine was made operational.

Table 1. Heat transmission values of coating layers

\begin{tabular}{llll}
\hline & $\mathrm{Fe}_{2} \mathrm{~B}$ & $\mathrm{NiCrBSi}$ & Grey cast iron \\
Tcc & $20-30$ & $7-17$ & 53,3 \\
$(\mathrm{~W} / \mathrm{m} . \mathrm{K})$ & & & \\
\hline
\end{tabular}

Tcc: Thermal conductivity coefficient

\section{Experimental Set Up}

Tests were basically classified as normal engine tests and thermal insulation engine (LHR) tests. A generator set with 4 cylinder, bench type, natural aspirated, $16.50 \mathrm{Kw} / 22$ $\mathrm{HP}$ power at fixed engine speed (1500 $\mathrm{rpm} / \mathrm{min}$ ) was used as the test engine. Table 2 illustrates technical properties of test engine. When normal and coated engines were tested, (ASTM-D-2) fuel was used as fuel. Table 3 illustrates technical properties of fuel. In our test engine, before going to measurements, the engine was operated for 15 mins to be stabilised, and measurements were made after the engine reached normal operating conditions. Tests were carried out under 4 brake powers including idle running of engine. Electrical brake powers were used as brake power. Brake power values were respectively $1^{\text {st }}$ load as $2.5 \mathrm{~kW}, 2^{\text {nd }}$ load as 5 $\mathrm{kW}$, and $3^{\text {rd }}$ load as $7.5 \mathrm{~kW}$. All tests which were performed with test engine were repeated 3 times and their arithmetic mean was calculated. Emission measurements were performed by using Bosch Brand BEA350 emission device. Table 4 illustrates technical properties of the device. A special mechanism was set to measure engine fuel consumption values and measurements were carried out via $100 \mathrm{ml}$ buret. For these measurements, each $10 \mathrm{ml}$ fuel consumption amount was recorded based on second by using chronometer. Figure 3 illustrates simulated image of the test mechanism. 
Temperature measurements were carried out through K-J type calorimeter from the end of exhaust system with the length of $110 \mathrm{~cm}$ beginning from exhaust manifold of engine.

Table 2. Technical properties of test engine

\begin{tabular}{ll}
\hline Item & Specification \\
\hline Type of engine & Aksa A4CRX18 \\
Stroke & 4 \\
Number of cylinders & 4 \\
Bore/stroke (mm) & $80 / 90$ \\
Compression ratio & $18.0: 1$ \\
Max. engine power $(\mathrm{kW})$ & $16.50(15001 / \mathrm{min})$ \\
Fuel type & Diesel \\
Lubricating & Full pressure \\
Type of injection & Direct injection \\
Type of coolant & Water coolant \\
Max. engine speed (1/min) & 3600 \\
Engine volume (Liter) & 1.80 \\
\hline
\end{tabular}

Table 3. Physical properties of diesel fuel

\begin{tabular}{ll}
\hline Properties & $\begin{array}{l}\text { Diesel } \\
\text { (ASTM-D:2) }\end{array}$ \\
\hline $\begin{array}{l}\text { Density }\left(15{ }^{\circ} \mathrm{C}, \mathrm{kg} / \mathrm{m}^{3}\right) \\
\text { Kinematic viscosity at }\end{array}$ & 850 \\
$40{ }^{\circ} \mathrm{C}(\mathrm{cst})$ & 3.05 \\
Calorific value $(\mathrm{kJ} / \mathrm{kg})$ & 42.800 \\
Flash point $\left({ }^{\circ} \mathrm{C}\right)$ & 56 \\
Fire point $\left({ }^{\circ} \mathrm{C}\right)$ & 63 \\
\hline
\end{tabular}

Table 4. Technical properties of emission device

\begin{tabular}{lll}
\hline Components & \multicolumn{1}{c}{$\begin{array}{c}\text { Measurement } \\
\text { Range }\end{array}$} & \multicolumn{1}{c}{ Precision } \\
\hline $\mathrm{CO}$ & $0.00-10.00 \%$ Vol. & $0.001 \%$ Vol. \\
$\mathrm{CO}_{2}$ & $0.00-18.00 \%$ Vol. & $0.01 \%$ Vol. \\
$\mathrm{HC}$ & $0-9.999 \mathrm{ppm}$ Vol. & $1 \mathrm{ppm}$ Vol. \\
$\mathrm{O}_{2}$ & $0.00-22.00 \%$ Vol. & $0.01 \%$ Vol \\
Lambda & $0.500-9.999$ & 0.001 \\
$\mathrm{NO}$ & $0-5000$ ppm Vol. & $\leq 1 \mathrm{ppm}$ Vol. \\
\hline
\end{tabular}

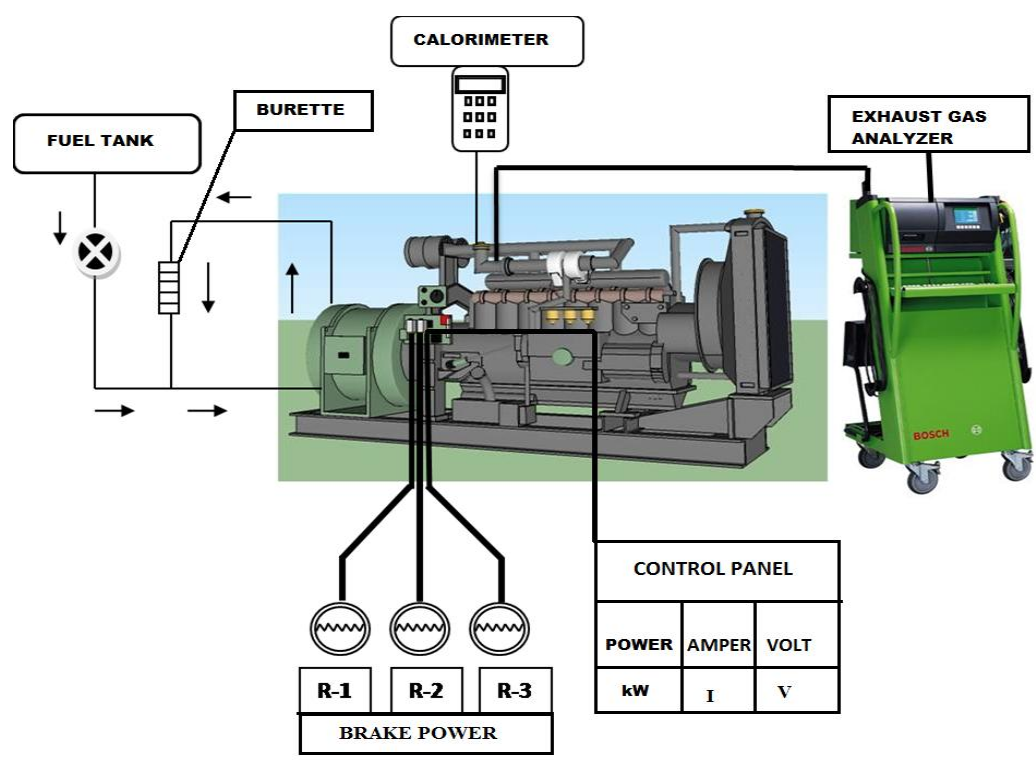

Figure 3. Image of testing apparatus

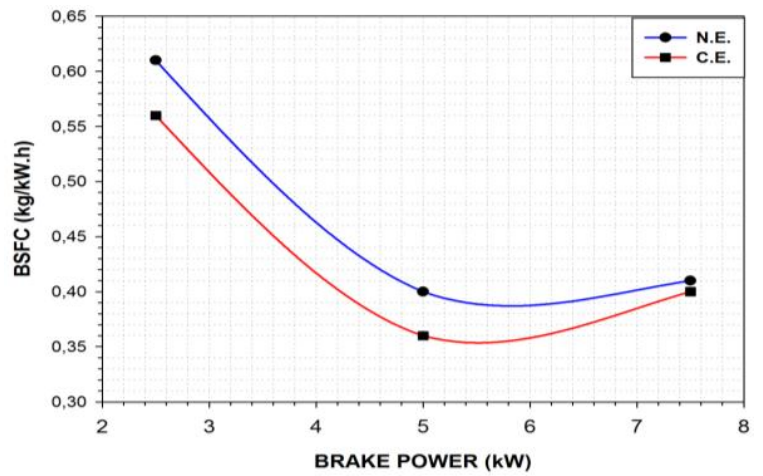

Figure 4. BSFC values of normal and coated engines

\section{Result and Discussion}

\subsection{Brake specific fuel consumption (BSFC)}

BSFC values of normal and coated engines measured under 3 different brake powers are shown in Figure 6 below.

As is seen from the graphic in Figure 4, BSFC values of coated engine indicated a decrease compared to normal engine under all implemented brake power values. If we evaluate BSFC values in terms of implemented brake powers, these values were high under low loads, low under medium loads, and increasing again under higher loads for both engines. Beginning from the moment that engine is loaded, that is, when passing from 1 st load to 2 nd load, BSFC value exhibited a sharp decrease. The reason for this sudden decrease is that the 
increase in the fuel consumption required to operate the engine fell behind the linear increase in the load. Additionally, this situation was associated with lower heat losses in the engine under high loads. While BSFC values for normal engine were respectively $0.61-0.40-0.41(\mathrm{~kg} / \mathrm{h}) / \mathrm{kW}$ for $1^{\text {st }}, 2^{\text {nd }}$, and $3^{\text {rd }}$ load, the same loads in coated engine were $0.56-0.36-040 \quad(\mathrm{~kg} / \mathrm{h}) / \mathrm{kW}$ respectively for the same loads. Decline percentages in BSFC values of coated engine based on load compared to normal engine were $8 \%-10 \%-2.5 \%$, respectively.

While BSFC value increased in lower speeds in both of the normal and coated engines, they decreased in medium speeds because of sufficient time within combustion chamber, suitable mixture formation, and higher combustion efficiency [3]. It is thought the fact that burn-out temperature, which increased because of thermal insulation in coated engine, the gas temperature within the chamber and combustion wall temperature increased affected BSFC values positively [4]. In addition, it was considered that shorter ignition delay period in LHR engines affected chemical and physical delays positively, which caused BSFC values to decrease in LHR engines [7-9].

\subsection{Brake specific energy consumption (BSEC)}

Figure 5 illustrates brake specific energy consumption changes of diesel engine at fixed rpm under different loads specific energy consumption measurement is an important parameter to compare brake thermal efficiency of engine.

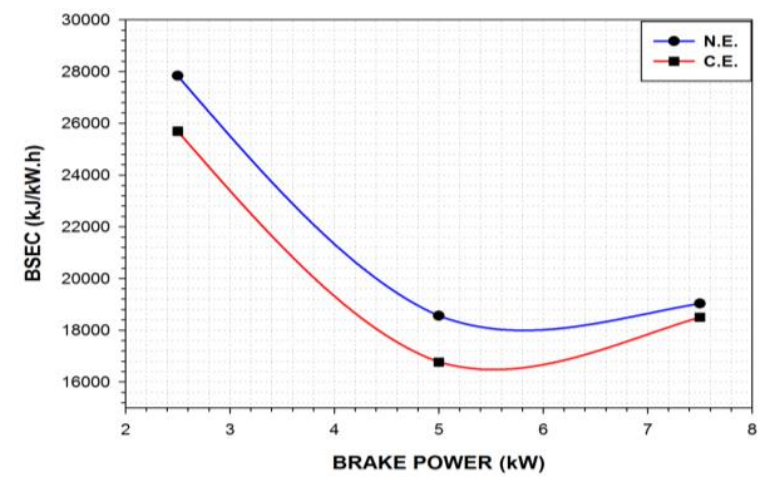

Figure 5. BSEC values of normal and coated engines

As is seen in the graphic in Figure 5, BSEC values of coated engine had lower values than the normal engine. It is understood that the coating process made positive contribution to BSEC values of engine and caused a substantial amount of decrease. BSEC values under $1^{\text {st }}, 2^{\text {nd }}$, and $3^{\text {rd }}$ brake power value of normal engine were 27835 , 18557 , and $19033 \mathrm{~kJ} / \mathrm{kW} . \mathrm{h}$ respectively, and BSEC values of coated engine were 25694, 16772, and $18504 \mathrm{~kJ} / \mathrm{kW} . \mathrm{h}$, respectively. Decline percentages in BSEC values of coated engine were $8 \%, 10 \%$, and $3 \%$ respectively based on loads. Since parameters such calorific value of fuel and output power are fixed data, when the coated engine was compared to normal engine, this decrease in BSEC value was associated with the decrease in SFC value. Since SFC value decreased because of the high gas and combustion wall temperature in combustion chamber of coated engine, BSEC value was lower than normal engine [3, 4].

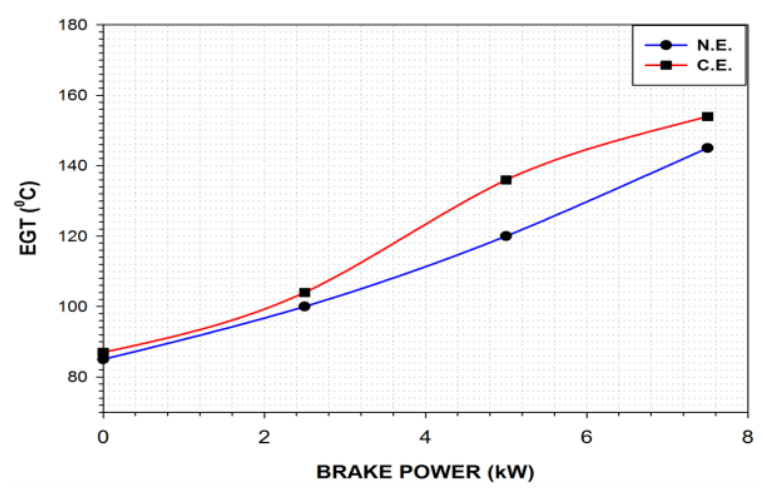

Figure 6. EGT values of normal and coated engines

\section{3. Exhaust gas temperature (EGT)}

Exhaust gas temperature measurements are an important parameter which enables us to comment on heat occurring as a result of combustion and temperature values that will occur due to this heat. As is seen from the graphic in Figure 6, exhaust gas temperature (EGT) values showed a linear increase together with the increasing brake power for both engines. EGT values under all load values gave higher results than normal engine. While this increase rose from $85 \mathrm{C}^{\circ}$ in $1^{\text {st }}$ load to $145 \mathrm{C}^{\mathrm{o}}$ in $3^{\text {rd }}$ load in normal engine, it increased from $87{ }^{\circ} \mathrm{C}$ to $168{ }^{\circ} \mathrm{C}$ in coated engine. When EGT values measured under $3^{\text {rd }}$ load value were compared, it was 
understood that EGT value of coated engine was $15 \%$ greater than normal engine's EGT value.

Since heat transmission to cooling water over combustion chamber elements decreased because of thermal barrier layer, more fuel is involved to combustion reaction. The heat occurring after reaction cycle was completed is released into atmosphere by using exhaust system. When compared to normal engine, EGT values in coated engine were high. As explained above, the main reason for this situation was the decreasing of heat going into cooling system and discharging of the remaining heat through exhaust. Similar studies have revealed affirmative results for our study [10].

\subsection{CO emissions}

$\mathrm{CO}$ is a reaction product that appears as a result of incomplete combustion and a harmful emission type depending on parameters such as air/fuel mixture ratio, oxygen amount, and engine temperature. As a result of combustion process, the entire oxygen is not transformed into $\mathrm{CO}_{2}$ and $\mathrm{CO}$ is observed in exhaust. The graphic in Figure 7 shows CO emission values of normal engine and coated engine.

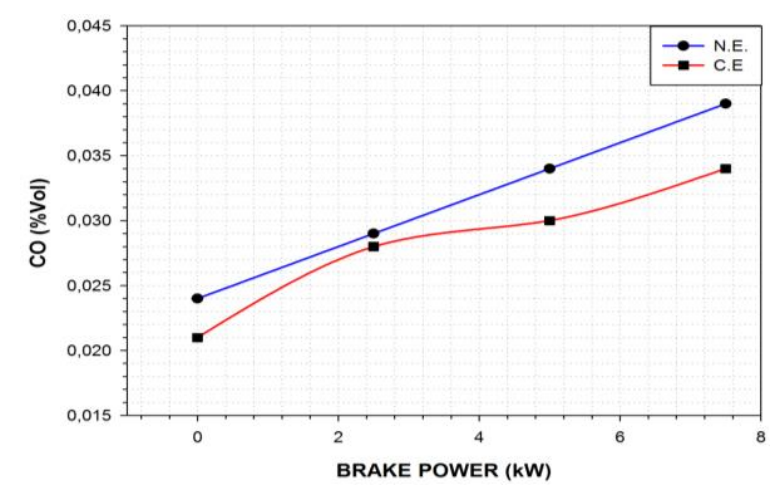

Figure 7. $\mathrm{CO}$ values of normal and coated engines

If we evaluate $\mathrm{CO}$ emission values of two engines; as is seen in the graphic in Figure 10 , when it is increased from low brake power to high brake power in both engines, $\mathrm{CO}$ emissions show an increase trend. $\mathrm{CO}$ emission values occurring under 4 brake power values of normal engine (\% vol.) were $0.024, \quad 0.029, \quad 0.034, \quad$ and $0.039 \%$ respectively. In coated engine, these values were $0.021,0.028,0.030$, and $0.034 \%$ respectively. Decline percentages in $\mathrm{CO}$ emissions of coated engine were 12.5-4-12 and $13 \%$ respectively based on brake power compared to normal engine. As is seen, $\mathrm{CO}$ emission values of coated engine were lower than normal engine under all the brake power values. $\mathrm{CO}$ is an emission type which occurs as a result of incomplete combustion of fuel and is related to parameters such as incylinder temperature and air/fuel rate $[7,11]$. Since burn -out temperature and combustion chamber pressure increase in LHR engines, $\mathrm{CO}$ emission is expected to be lower. In LHR engines, the decrease of pre-mixed combustion level reduces formation of $\mathrm{CO}$ emission at the beginning and then in other words during combustion process with diffusion, high temperature accelerated oxidation and reduced $\mathrm{CO}$ emission. With the compression-end temperature increased because of thermal insulation, combustion efficiency increased and this caused $\mathrm{CO}$ emission to reduce. In addition, since high temperature in LHR engines continued during expansion -exhaust- time of engine, it caused CO emission to reduce. Similar studies verify the results of our study $[7,12]$.

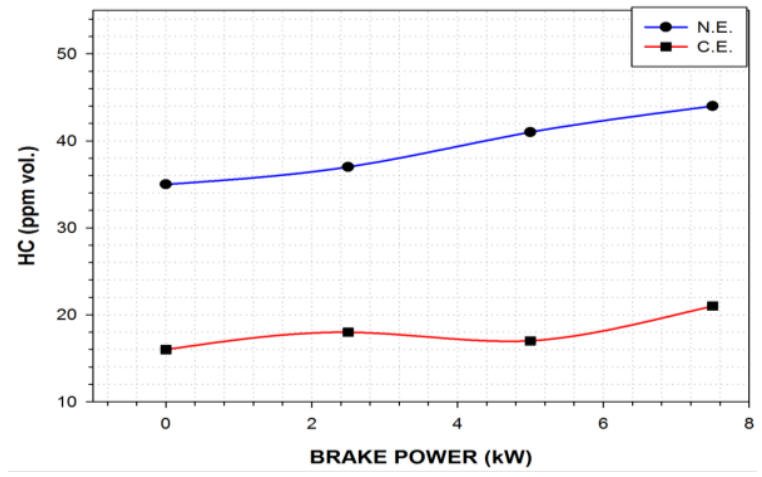

Figure 8. HC emission values of normal and coated engines

\subsection{HC emissions}

$\mathrm{HC}$ is an emission type seen in exhaust as a result of incomplete combustion of the fuel. Figure 8 illustrates $\mathrm{HC}$ emissions of normal and coated engines. When the graphic is examined, it is observed that $\mathrm{HC}$ emission generally increased with the increase of brake power for both engines. If we compared HC emission values of coated engine and normal engine; as seen from the graphic in figure 8, when the load moved from low to high in 
coated engine $\mathrm{HC}$ emissions generally showed an increase tendency as in normal engine. $\mathrm{HC}$ emission values in coated engine under all brake power values generally displayed a sharp decrease compared to normal engine.

$\mathrm{HC}$ emission (ppm) values of normal engine under 4 brake power values were $35,37,41$, and 44 respectively. In coated engine, these values were 16, 18, 17 and 21 (ppm) respectively. Decline percentages in $\mathrm{HC}$ emissions based on brake power in coated engine were $55,42,49$, and $43 \%$ respectively compared to normal engine. As is seen, HC emission values of coated engine were lower than normal engine under all brake power values. It is thought that $\mathrm{HC}$ emission mostly tended to decrease in LHR engines and helped to complete high in-cylinder gas and wall temperature oxidation reactions. Similar studies verify these results [12].

\subsection{NOx emissions}

NOx forms under sufficient temperature and oxygen concentration and chain reaction of $\mathrm{N}_{2}$ and $\mathrm{O}_{2}$. With the combining of different molecules of nitrogen and oxygen gases, various gases emerge, and all of them are called as "Nitrogen oxides" and expressed as NOx.

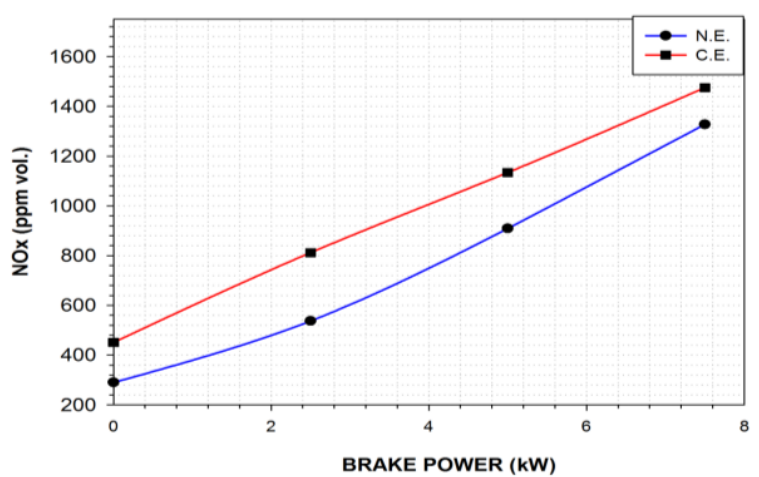

Figure 9. NOx values of normal and coated engines

The graphic in Figure 9 shows NOx emission values of normal engine and coated engines. As is seen in the graphic; while brake power increased in both engines, NOx concentration also showed a linear increase. NOx emission values of coated engine were higher than normal engine under all brake power values. NOx emission values of normal engine under 4 brake power values were 290, 537, 909, and 1327 (ppm vol.) respectively. In coated engine, these values were $451,812,1134$, and 1475 (ppm vol.) respectively. Increase percentages in NOx emission values of coated engine were 55, 51,25 , and $11 \%$ respectively compared to normal engine. As is seen, NOx emission values of coated engine were higher than normal engine under all brake power values. There are two basic kinetics of NOx formation. These are easily reacting of $\mathrm{O}_{2}$ with $\mathrm{N}$ at high temperature and increasing of air/fuel mixture ratio, and consequently oxygen concentration with the increase of brake power amount. In the test we performed, as the brake power rate increased, average gas temperature of combustion chamber increased rapidly depending on thermal insulation and this situation triggered NOx formation mechanism, which is sensitive against temperature, and increased NOx amount. On the other hand, since brake power increased, air/fuel ratios increased, and the increasing oxygen concentration and high gas temperature facilitated NOx formation $[9,13]$. On the other hand, while NOx emission values were directly proportional to EGT values, they were inversely proportional to $\mathrm{CO}$ and Smoke values. Results we obtained from the related emissions verify this proportional approach.

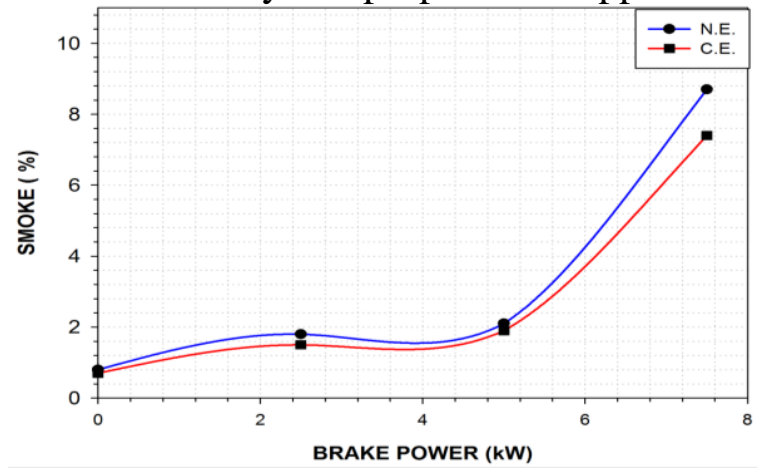

Figure 10. Smoke values of normal and coated engines

\subsection{Smoke emissions}

Even though the actual air/fuel ratio $(\mathrm{A} / \mathrm{F})$ is higher than theoretical combustion value during the combustion, there is not enough air around fuel drops within the cylinder. In this case, smoke (carbon particles), a product of incomplete combustion, occurs.

Figure 10 illustrates smoke emission graphic 
of normal and coated engines. As is seen from the graphic; as brake power increased, smoke values increased in both engines. This is thought to be associated with spraying of high amounts of fuel to combustion chamber in high brake power values and throwing out some of them from exhaust without combustion [13,14]. When normal engine was compared to coated engine in respect of Smoke values, coated engine had lower smoke value. If we compared smoke emission values of normal and coated engines with each other; Smoke emission values of normal engine under 4 brake power values were $0.8-1.8-2.1$ and $8.7(\%)$ respectively and these values were $0.7-1.5$ 1.9 , and $7.4(\%)$ respectively in coated engine. Decline percentages in Smoke emissions of coated engine were $12.5,-17$, 10 , and $15 \%$ respectively, compared to normal engine. As is seen, Smoke emission values of coated engine were lower than normal engine under all brake power values. This can be explained by the fact that cylinder wall and gas temperature increased because of thermal coating and more amounts of $\mathrm{C}$ reacted and smoke emission decreased because of high temperature. [4$6,8]$.

\section{Conclusions}

In assessment of performance results

$\checkmark \quad$ When both engines were compared in terms of BSFC values, coated engine had $7.5 \%$ lower BSFC value for the mean of 3 brake powers compared to normal engine. $\checkmark \quad$ When both engines were compared in terms of BSEC values, coated engine had $7 \%$ lower BSEC value for the mean of 3 brake powers compared to normal engine. $\checkmark$ When both engines were compared in terms of EGT values, coated engine had $15 \%$ higher EGT value for the mean of 3 brake powers compared to normal engine.

When emission results are assessed:

$\checkmark \quad$ When both engines were compared in terms of $\mathrm{CO}$ emission values, coated engine had $10 \%$ lower $\mathrm{CO}$ emission value for the mean of 3 brake powers compared to normal engine.
When both engines were compared in terms of $\mathrm{HC}$ emission values, coated engine had $47 \%$ lower $\mathrm{HC}$ value for the mean of 3 brake powers compared to normal engine.

$\checkmark \quad$ When both engines were compared in terms of NOx values, coated engine had $35 \%$ higher NOx value for the mean of 3 brake powers compared to normal engine. When both engines were compared in terms of Smoke emission values, coated engine had $14 \%$ lower Smoke emission value for the mean of 3 brake powers compared to normal engine.

\section{References}

[1] Miyairi Y. "Computer simulation of an LHR DI Diesel engine." SAE Paper No, 880187, 1989.

[2] Schwarz E, Reid M, Bryzik W, E. Danielson. "Combustion and Performance Characteristics of a Low Heat Rejection Engine", SAE Paper No, 930988, 1993.

[3] Hazar H, Ozturk U. "The effects of Al2O3- $\mathrm{TiO} 2$ coating in a diesel engine on performance and emission of corn oilmethyl ester." Renewable Energy 2010;35:2211-6.

[4] Mohamed Musthafa M, Sivapirakasam $\mathrm{S}$, Udayakumar $\mathrm{M}$. "Comparative studies on fly ash coated low heat rejection diesel engine on performance and emission characteristics fuel edbyricebran and pongamia methyl ester and their blend with diesel. Energy 2011;36:2343-51.

[5] Rajendra Prasath B, Tamilporai P, Shabir MF. "Analysis of combustion, performance and emission characteristics of low heat rejection engine using biodiesel". International Journal of Thermal Sciences. 2010;49:2483-90.

[6] Karthikeyan B, Srithar K. "Performance characteristics of a glowplugassisted low heat rejection diesel engine using ethanol"Applied Energy. 2011;88:323329.

[7] Hazar H. "Cotton methyl ester usage in a 
diesel engine equipped with insulated combustion chamber." Applied Energy 2010;87:134-40.

[8] Mohamedmusthafa M, Sivapirakasam S, Udayakumar M, Balasubramanian $\mathrm{K}$. "Effects of A12O3 coating on diesel engine performance, combustion, and emission characteristics fuel edbypongamia methyl ester and its blends with diesel." Environmental Progress\&SustainableEnergy. 2012;31:147-56.

[9] Haşimoğlu C, Ciniviz M, Ozsert İ, İçingur $\mathrm{Y}$, Parlak $\mathrm{A}$, Salman $\mathrm{MC}$. "Performance characteristics of a low heat rejection diesel engine operating with biodiesel." Renewable Energy. 2008;33:1709-15.

[10] Parlak A, Sahin B, Yasar H. "Perfornance optimisation of an irreversible dual cycle with respect to pressure ratio and temperatureratioexperimentalresults of a ceramic coated IDI Diesel engine." Energy Conversion \&Management. 2004;45:1219-32.

[11]Karabektas M. " The effects of turbocharger on the performance and exhaust emissions of a diesel engine fuelled with biodiesel". Renewable Energy 2009;34:989-93.

[12]Modi A, Gosai D. "Experimental study on thermal barrier coated diesel engine performance with blends of diesel and palm biodiesel". SAE Int J Fuel Lubricants 2010;3:246-59.

[13]Raheman H, Ghade SV. "Performance of compression ignition engine with Mahua (Madhucaindica) biodiesel. Fuel 2007;86:2568-73.

[14] Sukumar Puhana, N. Vedaramana, Boppana V.B. Rama, G. Sankarnarayananb, K. Jeychandranb "Mahuaoil (MadhucaIndicaseedoil) methyl ester as biodiesel-preparation and emission characterstics" Biomassand Bioenergy. 28;2005:87-93. 